\title{
DE REGRESO AL ENSAYO DE UN CRIMEN
}

POR

\author{
ILAN STAVANS \\ Columbia University
}

Una razón misteriosa mantiene olvidada Ensayo de un crimen, una novela de 1944 de Rodolfo Usigli, el mismo Usigli de Corona de sombra y El gesticulador. La novela es un primor - la semilla irrebatible de las letras policiales que florecen hoy en América Latina. Paco Ignacio Taibo II, creador del prosaico private-eye mexicano Héctor Belascoarán Shayne, lista a Rafael Bernal como precursor de la tradición, pero ignora el libro de Usigli. Lo mismo hacen los especialistas Donald A. Yates y Juan Jacobo Bajarlía, quienes ven a Borges, Rodolfo J. Walsh, Adolfo Bioy Casares, Manuel Peyrou, Antonio Helú y María Elvira Bermúdez, entre otros, como piedras angulares, sin jamás incluir Ensayo de un crimen, obra de la cual Luis Buñuel hizo una adaptación cinematográfica en 1955. La amnesia es lamentable, sí, pero no asombra. Por dos razones: una, porque se trata, al fin y al cabo, de la única novela del autor, un satirista nacido en 1905 y muerto setenta y cuatro años más tarde, que escribió dramas históricos, comedias y ensayos acerca de la realidad mexicana, y que por ellos fue reconocido. Y dos, porque también están ignorados otros pilares, tan o más valiosos, tan o menos destacados; un ejemplo: "El triple robo de Bellamore", un cuento de Horacio Quiroga de 1903. Lo que implica que, con excepción de España, en los países de habla castellana es aún desconocida la prehistoria de semejante literatura. Leemos a Cortázar, loargüengoitia o Thorndyke como si surgieran del vacío.

Al leerla, nadie dudará que se trate de un texto anacrónico. Su protagonista es Roberto de la Cruz, undandy que vive con la aspiración de cometer un crimen estético perfecto. La intimidad de este burgués desenfadado y necio se enmarca en los años cuarenta, mientras México hierve en un conflicto petrolero y el mundo, en una guerra total. Lo caprichoso de la labor de Usigli estriba en dedicar trecientas y pico de páginas a una serie de crímenes platónicos en este escenario donde se mata por amor, ideología, dinero o envidia pero rara vez por belleza. Además, lo que el escritor deja afuera es tan importante como lo que incluye. El país cruza un período de intenso patriotismo y una de sus mil sacudidas financieras, pero nada de esto preocupa a de la Cruz, que vive como 
en una burbuja de vidrio, aislado y demostrando sus atributos ególatras. Sufre, odia e imagina proyectos inaceptables y ridículos o bondadosos y humanos en una ciudad que igual podría ser San Petersburgo, Londres o México. Y no al azar escojo estas referencias: aunque el escritor era un confesado admirador de George Bernard Shaw, la inspiración le viene a Ensayo de un crimen del Dostoievski de Crimen y castigo y de Thomas De Quincy, en especial Murder Considered as One of the Fine Arts. De la Cruz vive a diario poseído por una fuerza interior que es brutal y que lo persigue sin tregua. Sus ataques arrancan cuando oye "El príncipe rojo", un vals de Waldteufel que surge de una caja musical que recibió en la infancia. Al escucharlo, pierde sus cabales, se desboca y siente ganas de acabar con vidas ajenas. Ni roba ni viola (dos de sus víctimas son mujeres, la tercera un homosexual); sus asesinatos se proponen liberar al prójimo de "tipejos" desagradables, de la escoria que todos aborrecen y que él, sólo él, puede eliminar. Así, de la Cruz es similar a Rashkolnikov, porque mata pensando en la humanidad, y rinde tributo a De Quincy, porque lo marea la sangre y aborrece la violencia y porque, como buen antinomiano, confía en que el asesinato es de alguna forma una de las modalidades del Bien.

A continuación, un puñado de datos que conforman el suspenso: abre la novela con de la Cruz rasurándose con agua hervida y una navaja filosa. De pronto, siente que la cabeza se le cae del cuello y lo recorre un sudor frío. Sabemos poco de su pasado; sólo del presente. Tendrá como máximo unos cuarenta y cinco años. Su malestar le hace recordar en voz alta el verso "iA dónde van los muertos, señor? ¿A dónde van?”. Quiere asesinar y no sabe controlarse. Su primera víctima será una odiosa adinerada, Patricia Terrazas. De la Cruz programa treinta pasos a seguir, pero justo al llegar a Yucatán no. 48, el domicilio del futuro cadáver, alguien se le ha adelantado. ¿Quién?; ni él ni nosotros lo sabemos. Ve una silueta simiesca (¿un homenaje a Poe?) con una cámara fotográfica que sale de la mansión y piensa que se trata del causante. Lo posee, sin embargo, una tristeza profunda: había venido a matar y no lo ha logrado. Decide, pues, que fue suyo el asesinato, suyo y de nadie más, y dejar sus huellas digitales por doquier. Pronto es encerrado en una penitenciaría y, en breve, absuel to. Otra vez intenta otra proeza similar, ésta contra otro dandy; y una tercera, contra una de sus amantes. Al final, como es la costumbre, quedan claros los hechos gracias a la deducción del ex inspector Herrera, una presencia fantasmal que juega al papel de deus absconditus: aparece ante de la Cruz en las ocasiones más inesperadas, le avisa cuando está cerca la fatalidad y lo investiga sin entrometerse.

La película de Buñuel dista de la trama original. Al tiempo de lucir un surrealismo nuevo, desprecia la faceta de roman a cléf. Según rumores, la adaptación iba a ser de Usigli y de Buñuel juntos, pero los separó un altercado y la terminó un amigo del director. Al ver el producto final, Usigli se quejó ante un sindicato, pero no había nada que hacer porque se había aclarado "Inspirada 
en ...”. (En la cinta el libreto es de Buñuel y Eduardo Ugarte). De hecho, el director español cambió el título en el extranjero por La vida criminal de Archiblado de la Cruz, o sea que alteró el nombre del protagonista (actuado por Ernesto Alonso). Transformó muchas cosas más: de la Cruz, por ejemplo, sueña con matar a tres mujeres (Adriana Welter, Miroslava y Rita Macedo); hay maniquís y abunda el fetichismo; etc.

De escoger, me quedo con la versión de Usigli porque fluye mejor, es más liviana y menos pretenciosa. En ella los sentimientos del antihéroe lo empujan a buscar su objeto y destino vitales, la razón que justifique su existencia. Vive solo en una habitación rentada de hotel. Sus conductas son forzadas y están guiadas por las mismas corazonadas que siguen las criaturas de Proust. Cuando lo vemos, siempre está bebiendo brandy o un highball o jugando poker con amigos diplomáticos. También aparece comiendo en restaurantes de muy alta calidad, yendo a Cuernavaca y Acapulco, hojeando las Rimas de Bequer o fumando uno de sus Lucky. Robert Louis Stevenson, en su asombrosa The Wrecker, confiesa que los personajes de una novela policial corren el riesgo de resultar meras tuercas de un mecanismo que los rebasa. Nada de esto ocurre enEnsayo de un crimen, cuyos secretos apasionan como lo hacían los de Dorothy L. Sayers y Agatha Christie. Hay, cierto, escenas artificiales; conté cinco en total: en una el antihéroe se corta las venas sin motivo aparente; en otra hay un accidente de automóvil, cuya única razón de ser es la de eliminar al reparto superfluo. Por fortuna estas "inconveniencias" son mínimas y no abruman. La descripción, minuciosa y sabia, de la Ciudad de México, desde la visión elitista y no de la popular, i.e., haciendo alusiones a los mil callejones y cafeterías de alcurnia, los centros de reunión y estanquillos de periódicos, es la urgencia donde se desempeña Usigli —quien por su economía e intereses, por su pasión estética, es la antítesis de su compatriota Juan Rulfo.

Alfonso Reyes, uno de los aficionados a la novela de detectives, discutió sus fronteras en 1945 y 1959, aunque jamás habló de la contribución nativa. Carlos Monsiváis sí lo hizo, aunque con desprecio, argumentando que la práctica mexicana (y por sinécdoque, de gran parte de América Latina) es imitativa y nada estimulante. Imitativa, a veces, no siempre; poco estimulante, no. Basta invocar a Erik Lönnrot, al pintor de Sábato, la continuidad a los parques y a eme de José Emilio Pacheco. Basta invocar, asimismo, esta divertida novela de Usigli, cuya trama e improbable y emblemático antihéroe deleitan a casi medio siglo de distancia. 
